\title{
Superior Solubility and Dissolution of Zaltoprofen via Pharmaceutical Cocrystals
}

\section{Farmasötik Cocrystal ile Zaltoprofen'in Üstün Çözünürlük ve Çözünmesi}

\author{
(D) Prabhakar PANZADE*, (D) Giridhar SHENDARKAR \\ Center for Research in Pharmaceutical Sciences, Nanded Pharmacy College, Opp. Kasturba Matruseva Kendra, Sham Nagar, Nanded, India
}

\begin{abstract}
Objectives: Pharmaceutical cocrystals are a promising tool to enhance the solubility and dissolution of poorly soluble drugs. Zaltoprofen (ZFN) is nonsteroidal anti-inflammatory drug with a prevalent solubility problem. The present study was undertaken to enhance the solubility and dissolution of ZFN through pharmaceutical cocrystals by screening various coformers.

Materials and Methods: Cocrystals of ZFN were prepared in 1:1 and 1:2 ratio of drug:coformer by the dry grinding method. The melting point and solubility of the crystalline phase were determined. The potential cocrystals were characterized by differential scanning calorimetry (DSC), infrared spectroscopy, and powder X-ray diffraction (PXRD). Cocrystals were subjected to dissolution rate and stability study.

Results: ZFN-nicotinamide (NIC) cocrystals demonstrated deviation in melting point and solubility. The cocrystals were obtained in both 1:1 and 1:2 ratios with NIC. The infrared analysis noticeably indicated the shifting of characteristic bands of ZFN. The crystallinity of the cocrystals was evident from the XRPD pattern and notable difference in the $2 \theta$ values of intense peaks. The DSC spectra of the cocrystals exhibited altered endotherms analogous to melting point. The cocrystals showed a faster dissolution rate and a $55 \%$ increase in the extent of dissolution compared to pure drug. The cocrystals were stable at room temperature and accelerated conditions.

Conclusion: The prepared cocrystals exhibited greater solubility and dissolution compared to the pure drug and were stable at room temperature and accelerated conditions.
\end{abstract}

Key words: Pharmaceutical cocrystal, zaltoprofen, solubility, dissolution

\section{ÖZ}

Amaç: Farmasötik kokristal, zayıf çözünür ilaçların çözünürlüğünü ve çözünmesini arttırmak için umut veren bir araçtır. Zaltoprofen (ZFN) yaygın çözünürlüğe sahip nonsteroid antiinflamatuvar ilaçtır. Bu çalışma, çeşitli koformerlerin taranması yoluyla farmasötik kokteyli aracılığıyla ZFN'nin çözünürlügünü ve çözünmesini arttırmak için üstlenilmiştir.

Gereç ve Yöntemler: Kuru ögü̈tme yöntemi ile 1:1 ve 1:2 oranında ilaç:koformer oranında ZFN kristalleri hazırlanmıştır. Erime noktası ve kristalin fazın çözünürlüğü belirlenmiştir. Potansiyel kristaller differansiyel tarama kalorimetrisi (DSC), kızılötesi spektroskopi ve toz X ışını kırınımı (PXRD) ile karakterize edilmiştir. Kokristaller çözünme hızına ve stabilite çalışmasına tabi tutulmuştur.

Bulgular: ZFN-nikotinamid (NIC) kokristal erime noktasında ve çözünürlükte sapma göstermiştir. Kristaller, NIC ile hem 1:1 hem de 1:2 oranında elde edilmiştir. Kızı̈̈tesi analizi, ZFN karakteristik bantlarının kaymasını belirgin bir şekilde göstermiştir. Kristallerin kristallenmesi XRPD paterninden belirgin olarak görülmüştür ve $2 \theta$ değerindeki yoğun zirvelerdeki kayda değer farklılıklar gözlenmiştir. Kristallerin DSC spektrumları, erime noktasına benzer değiştirilmiş endotermler sergilemiştir. Kristaller, daha hızlı çözünme oranı ve saf ilaçla karşılaştırıldığında çözünme derecesinde \% 55 artış göstermiştir. Kristaller, oda sıcaklığında ve hızlandırılmış koşullarda kararlı bulunmuştur.

Sonuç: Hazırlanan kristaller, saf ilaca kıyasla daha fazla çözünürlük ve çözünme sergilemiş ve oda sıcaklığında ve hızlandırılmış koşullarda sabit bulunmuştur.

Anahtar kelimeler: Farmasötik kokristal, zaltoprofen, çözünürlük, çözünme

*Correspondence: E-mail: prabhakarpanzade@gmail.com, Phone: +91-9921830320 ORCID-ID: orcid.org/0000-0003-1247-9197

Received: 24.03.2018, Accepted: 07.06.2018

๑Turk J Pharm Sci, Published by Galenos Publishing House. 


\section{INTRODUCTION}

After oral administration the solubility and dissolution rate of a drug are crucial factors for its sufficient bioavailability. These factors are the main challenge to the formulation scientist for the development and formulation of effective drugs. More than $40 \%$ of drugs in development suffer from bioavailability problems owing to poor solubility. Alternative strategies have been introduced to enhance solubility, the dissolution rate, and bioavailability. These involve salt formation, solid dispersion, cyclodextrin complexation, microemulsification, solubilization, micronization, etc. ${ }^{1-4}$

Recently pharmaceutical cocrystals have attracted considerable attention from formulation experts busy in formulation development. Due to the inherent thermodynamic stability of crystalline active pharmaceutical ingredients (APIs), these are preferred in the pharmaceutical industry. Pharmaceutical cocrystals have emerged as an effective tool to tailor the physical properties of APIs like solubility and dissolution along with stability. The principal advantage of this technique is that the pharmacological effect of the drug remains unchanged. ${ }^{5-7}$ Cocrystals are defined as stoichiometric multicomponent systems united by noncovalent interactions in which two diverse components are solid under ambient conditions. The documented advantages of cocrystals are improved stability against humidity, chemical stability, improved dissolution and bioavailability, and tabletability. Various methods were studied to enhance solubility like hydrotropy and solid dispersion. To the best of our knowledge, pharmaceutical cocrystals of zaltoprofen (ZFN) have not been reported to date..$^{8-14}$

ZFN is a nonsteroidal anti-inflammatory propionic acid class drug. It is used in the treatment of acute and chronic inflammation and rheumatoid arthritis. It is practically insoluble in water and associated with side effects like ulcerogenicity, bellyache, and indigestion. Moreover, ZFN is weakly ionizable and so salt formation cannot enhance the solubility of the drug. Rapid onset and improved bioavailability are desired for analgesics. Hence there is a strong scientific and clinical need to prepare novel forms of ZFN possessing modified solubility and dissolution rates that can be formulated for oral administration. Accordingly, the aim of the present study was to prepare novel pharmaceutical cocrystals of ZFN with improved solubility and dissolution. 15,16

\section{MATERIALS AND METHODS}

\section{Materials}

ZFN was received as a gift sample from ICPA Laboratory Ltd. (Mumbai, India). All other chemicals were purchased from the SD Fine Chemicals (Mumbai, India). Double distilled water was used throughout the research.

\section{Preparation of cocrystals}

The dry grinding method was adopted for the preparation of ZFN cocrystals. The drug and coformers were mixed in different molar ratios (1:1 and 1:2) in a mortar and pestle for 45 min to form cocrystals. They were dried overnight at ambient temperature and stored in tight containers. ${ }^{17}$ Twenty-five coformers were screened for the preparation of cocrystals, i.e. salicylic acid, nicotinamide (NIC), glutaric acid, malonic acid, benzoic acid, tartaric acid, oxalic acid, citric acid, urea, succinic acid, saccharine sodium, Pluronic 68 AR, magnesium stearate, crotonic acid, P-hydroxy benzoic acid, caffeine, 3,5 dihydroxy benzoic acid, piperazine citrate, cinnamic acid, adipic acid, hydroquinone, isonicotinic acid, acetamide, maleic acid, and ascorbic acid.

\section{Evaluation of cocrystals}

\section{Drug content}

Cocrystal powder equivalent to $10 \mathrm{mg}$ of drug was accurately weighed and dissolved in a $10 \mathrm{~mL}$ volumetric flask and the volume was adjusted with phosphate buffer $\mathrm{pH}$ 6.8. The resulting solution was filtered, suitably diluted, and the absorbance of the solution was measured at $243 \mathrm{~nm}$ (Shimadzu UV 1800). ${ }^{18}$

\section{Determination of melting points}

Melting points of the compounds were determined using a digital melting point apparatus (Labtronics Ltd).

\section{Saturation solubility}

An excess amount of pure drug and cocrystals were dissolved in $10 \mathrm{~mL}$ vials containing the drug to estimate solubility. The vials were agitated on rotary shaker and allowed to stand for equilibration for $24 \mathrm{~h}$. The samples were filtered after 24 h, suitably diluted with distilled water, and analyzed by UV spectrophotometer at $243 \mathrm{~nm}$.

\section{Infrared spectroscopy}

Infrared (IR) spectroscopy was employed to determine the possible interaction between the drug and coformers. Samples were mixed with potassium bromide and compressed into discs before scanning between 4000 and $400 \mathrm{~cm}^{-1}$ with resolution of $4 \mathrm{~cm}^{-1}$ by Shimadzu IR spectrophotometer.

\section{Differential scanning calorimetry}

The thermal behavior of the drug alone and cocrystals was determined on a Mettler Toledo DSC 822e Module. Weighed samples were loaded into an aluminum pan before crimping and heated at a rate of $5^{\circ} \mathrm{C} / \mathrm{min}$, covering the 0 to $300^{\circ} \mathrm{C}$ temperature range, under a nitrogen stream. The instrument was calibrated using indium and an empty aluminum pan was used as a reference.

\section{Powder X-ray diffraction}

Silicon sample holders were utilized to get diffraction patterns for pure ZFN and cocrystals (Bruker D8 Advance diffractometer). The instrument was equipped with a fine focus $\mathrm{X}$-ray tube and each sample was placed onto a goniometer head that was motorized to permit spinning of the sample during data acquisition.

\section{In vitro dissolution study}

Pure ZFN and its cocrystals were subjected to dissolution study by USP type II apparatus (Electrolab, Mumbai, India). The dissolution study was performed in $900 \mathrm{~mL}$ of $\mathrm{pH} 6.8$ 
phosphate buffer at $37 \pm 0.5^{\circ} \mathrm{C}$ and $50 \mathrm{rpm}$ for $60 \mathrm{~min}$. The pure drug and cocrystals equivalent to $80 \mathrm{mg}$ of drug were used for the study. Then $5 \mathrm{~mL}$ samples were withdrawn after specified time intervals and analyzed by UV spectrophotometer at 243 nm. ${ }^{19}$

\section{Stability study}

The selected cocrystals were subjected to a stability study at room temperature and $40 \pm 2^{\circ} \mathrm{C}$ with $75 \pm 5 \%$ RH for 3 months. A sample of $1 \mathrm{~g}$ was placed in an eppendorf tube in a stability chamber throughout the stability duration and analyzed after 30 days, 60 days, and 90 days. Different attributes were studied to assess the stability, i.e. drug content, melting point, solubility, in vitro drug release, etc.

\section{RESULTS AND DISCUSSION}

The 25 coformers were screened to prepare cocrystals with ZFN by the dry grinding method. The coformers were selected based on a literature survey and to increase the chances of formation of new cocrystals. Among the various coformers studied, NIC successfully interacted with ZFN, giving novel cocrystal forms. The obtained ZFN cocrystals were subjected to evaluation and stability studies.

\section{Drug content}

The drug content of ZFN-NIC $1: 1$ and 1:2 cocrystals was determined in phosphate buffer $\mathrm{pH} 6.8$ as $95.87 \pm 0.98 \%$ and $95.88 \pm 1.10 \%$, respectively.

\section{Melting points and saturation solubility}

The melting points of pure drug, coformers, and cocrystals were estimated and are reported in Table 1. In addition, the saturation solubility of pure drug and cocrystals was also determined and is reported in Table 1. These parameters were used for preliminary screening of the cocrystals. The melting points of the ZFN-NIC cocrystals were lower than that of the pure drug. This may be attributed to the multicomponent system and the probable formation of cocrystals. The altered melting points might be due to an interaction between ZFN and NIC, modified crystallinity of molecules, or distinct packing arrangement. This interaction results in an altered molecular arrangement, which leads to novel crystal forms with distinct physical properties. ${ }^{20,21}$

The solubility of a few cocrystals was improved but ZFNNIC cocrystals exhibited a remarkable increase in solubility, indicating successful interaction of drug and coformer. However, greater solubility was obtained with ZFN-NIC 1:2 cocrystals $(1.516 \pm 0.467 \mathrm{mg} / \mathrm{mL})$ than with $1: 1 \quad(0.926 \pm 0.134$ $\mathrm{mg} / \mathrm{mL}$ ). The ZFN-NIC 1:1 and 1:2 cocrystals showed 42-fold and 66 -fold increases in solubility in comparison to the pure drug. The results were compared using Dunnet's test and statistically significant differences were found in solubility $(p<0.05)$ between the pure drug and cocrystals. This indicates an interaction between ZFN and NIC leading to cocrystal formation. The interaction between the oxygen atom of the drug and the primary amide hydrogen of the NIC might have formed the cocrystal. Similar studies were reported on cocrystals of meloxicam, lornoxicam, aceclofenac, etc. ${ }^{22,23}$
On the basis of the results, ZFN-NIC 1:1 and 1:2 cocrystals were further characterized and confirmed.

\section{IR spectroscopy}

The IR spectra for the pure drug, coformer, and ZFN cocrystals were recorded and are shown in Figures 1 and 2. The principle bands were identified and related changes were recorded. The IR spectrum of pure ZFN shows the presence of the characteristic peaks, which were recorded at $1699 \mathrm{~cm}^{-1}$ and 1668 $\mathrm{cm}^{-1}$ for stretching of the carboxylic group, -C-S-C- aromatic stretching peaks observed at $939.39 \mathrm{~cm}^{-1}, \mathrm{OH}$ stretching in the carboxylic group at $2950 \mathrm{~cm}^{-1}$, and $\mathrm{CH}_{3}$ stretching at $1330 \mathrm{~cm}^{-1}$. The IR spectrum of NIC revealed an absorption band at 3145 $\mathrm{cm}^{-1}$ for $\mathrm{NH}_{2}$ stretching of primary amide and $3342 \mathrm{~cm}^{-1}$ for the pyridine ring region, $\mathrm{NH}$ bending is observed at $1593 \mathrm{~cm}^{-1}$, and aromatic $\mathrm{C}=\mathrm{C}$ peaks are observed at $1614 \mathrm{~cm}^{-1}$. These spectra are in good agreement with the published data. The IR bands were significantly changed in the cocrystals in comparison to the pure drug and coformer, indicating an interaction between drug and coformer. ${ }^{24}$

In the case of the 1:1 cocrystal changes were observed in the peaks corresponding to carboxylic group stretching, which was observed at $1634 \mathrm{~cm}^{-1}, \mathrm{OH}$ stretching at $3000 \mathrm{~cm}^{-1}$ in comparison to the drug, and $\mathrm{NH}_{2}$ stretching and $\mathrm{NH}$ bending at 3450 and $1583 \mathrm{~cm}^{-1}$ as compared to NIC and $1654 \mathrm{~cm}^{-1}, 3000 \mathrm{~cm}^{-1}, 3300$ $\mathrm{cm}^{-1}$, and $1583 \mathrm{~cm}^{-1}$ for the $1: 2$ cocrystal, respectively.

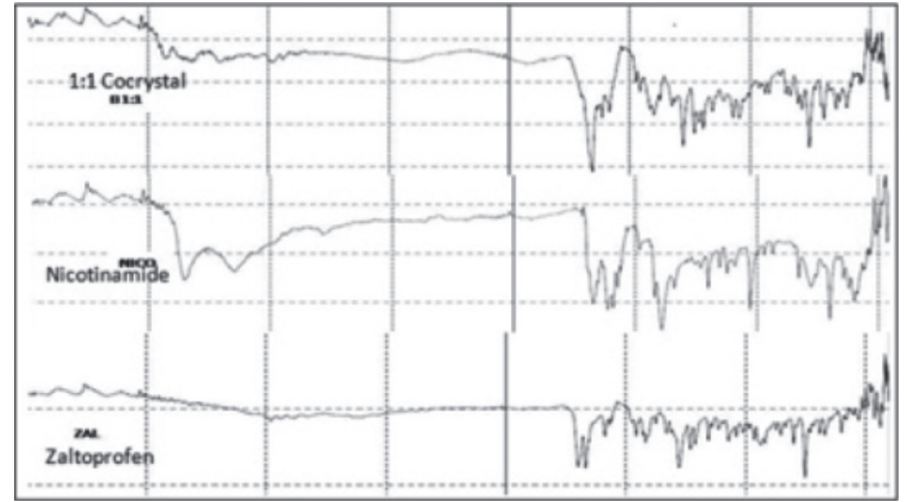

Figure 1. Overlay IR spectra of 1:1 cocrystal

IR: Infrared spectroscopy

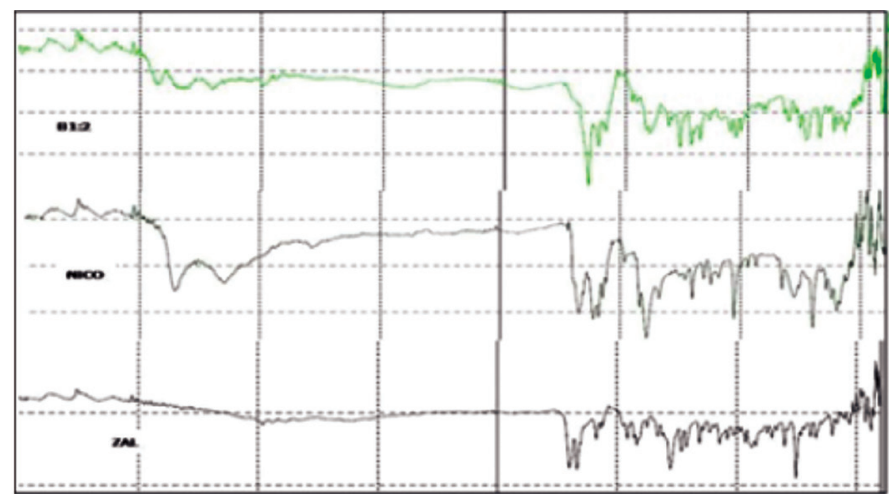

Figure 2. Overlay IR spectra of 1:2 cocrystal

IR: Infrared spectroscopy 
A new peak at $3450 \mathrm{~cm}^{-1}$ and one at $3400 \mathrm{~cm}^{-1}$ were observed, indicating the formation of a hydrogen bond between the drug and coformer in the ZFN-NIC 1:1 and 1:2 cocrystals, respectively, prepared by the neat grinding method. ${ }^{25}$

Similar changes in the IR spectra of other drugs like piroxicam and hydrochlorothiazide were reported and considered as a sign of cocrystal formation. ${ }^{26,27}$ Hence the changes recorded in the present study can be regarded as a indicator of cocrystal formation between the drug and coformer.

\section{Differential scanning calorimetry}

ZFN, NIC, and ZFN-NIC cocrystals were characterized by DSC. The pure drug and NIC showed characteristic endothermic peaks at $137.69^{\circ} \mathrm{C}$ and $129.67^{\circ} \mathrm{C}$, respectively, corresponding to their melting points. Similar thermal behavior was reported for the drug and coformer. ${ }^{28}$
ZFN-NIC (1:1 and 1:2) cocrystals exhibited melting points at $109.20^{\circ} \mathrm{C}$ and $123.50^{\circ} \mathrm{C}$, respectively, which are significantly different from that of the pure drug. Moreover, the peak onset for the pure drug was obtained at $131.52^{\circ} \mathrm{C}$ and at $102.40^{\circ} \mathrm{C}$ and $120.02^{\circ} \mathrm{C}$ for $1: 1$ and $1: 2$ cocrystals, respectively.

The changes in the thermal properties were reported as evidence for the formation of cocrystals. ${ }^{29}$ Hence the present investigation indicates the formation of cocrystals (Figure 3 ).

\section{Powder X-ray diffraction}

The powder X-ray diffraction (PXRD) patterns for ZFN, NIC, and ZFN-NIC cocrystals are shown in Figures 4 and 5 . The materials in the powder state give different peaks of varying intensities at certain positions. The diffractogram of the ZFN showed characteristic numerous sharp, intense diffraction peaks at

Table 1. Melting point and solubility of cocrystals

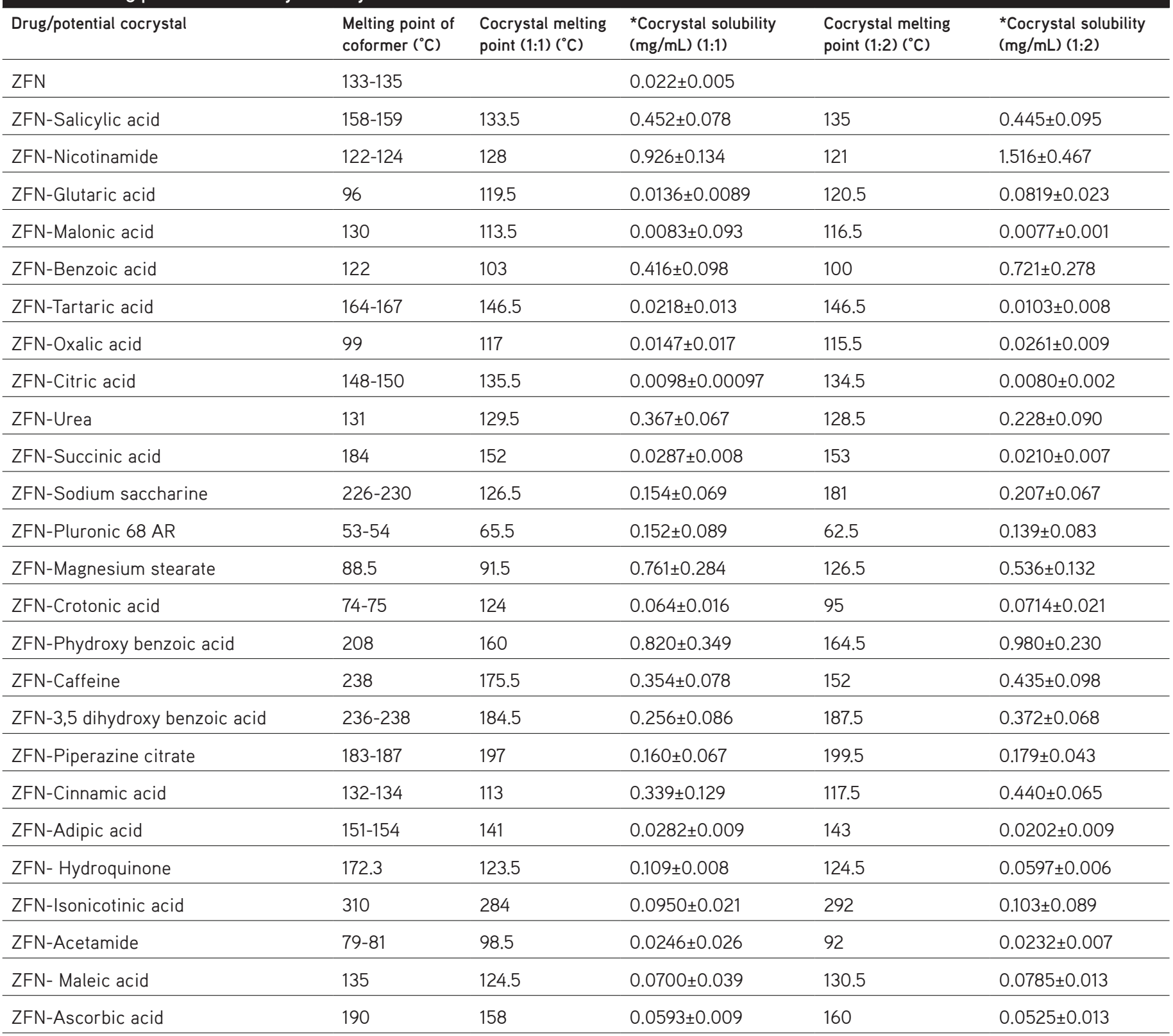

ZFN: Zaltoprofen, *Average of three determinations mean \pm standard deviation 
different $2 \theta$ values $(15,17.5,19,31,32.5$, and 42), indicating a crystalline nature. In addition, the diffraction peaks obtained for NIC were 25, 30, 34.5, 37, 47.5, and $50.52 \theta$ values. Similar diffraction patterns were reported in previous investigations. The PXRD pattern of the cocrystal was distinguishable from that of its components and some additional diffraction peaks appeared that did not exist in the pure drug or coformer. The additional diffraction peaks for 1:1 and 1:2 cocrystals were obtained at $2 \theta$ values of $16,17,18,19,20,30.5$, and 37.5 and 17.5, 18.5, 26.5, 34.5, 37.5, 40.5, and 50.5, respectively. The appearance of new diffraction peaks in the diffractogram of cocrystals shows the formation of a new crystalline phase

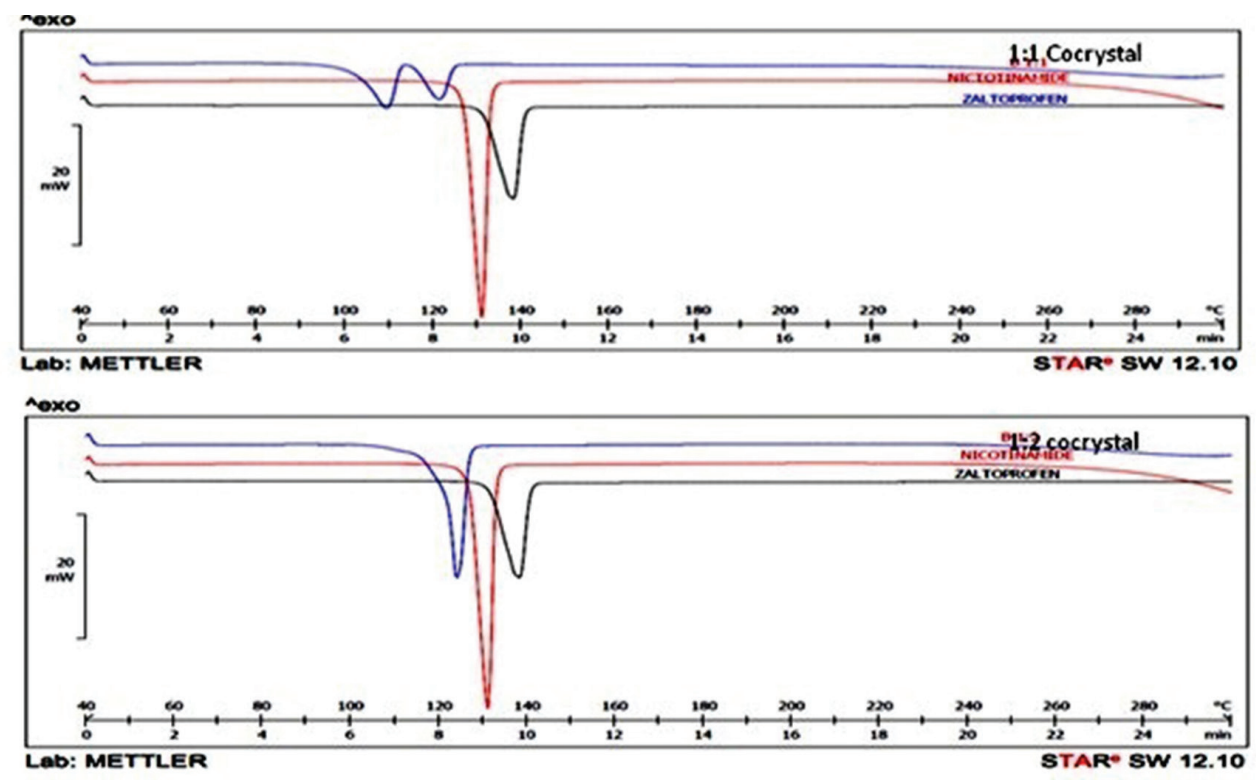

Figure 3. Overlay DSC thermogram of 1:1 and 1:2 cocrystals

DSC: Differential scanning calorimetry

Table 2. Stability study of cocrystals

\begin{tabular}{|c|c|c|c|c|c|c|c|}
\hline \multirow[t]{2}{*}{ Parameters } & \multirow[t]{2}{*}{ Sampling } & \multirow{2}{*}{$\begin{array}{l}\text { Zaltoprofen } \\
\text { (accelerated) }\end{array}$} & \multirow{2}{*}{$\begin{array}{l}\text { Zaltoprofen } \\
\text { (room } \\
\text { temperature) }\end{array}$} & \multicolumn{2}{|c|}{$\begin{array}{l}\text { Cocrystal neat grinding } \\
\text { (accelerated) }\end{array}$} & \multicolumn{2}{|c|}{$\begin{array}{l}\text { Cocrystal neat grinding (room } \\
\text { temperature) }\end{array}$} \\
\hline & & & & $1: 1$ & $1: 2$ & $1: 1$ & $1: 2$ \\
\hline \multirow{4}{*}{ Melting point $\left({ }^{\circ} \mathrm{C}\right)$} & Initial & $133-134$ & $133-134$ & $111-114$ & $120-121$ & $111-114$ & $120-121$ \\
\hline & 1 month & $133-134$ & $133-135$ & $114-115$ & $115-117$ & $116-117$ & $124-126$ \\
\hline & 2 month & $132-133$ & $131-133$ & $115-118$ & 117 & $116-118$ & $115-117$ \\
\hline & 3 month & $132-134$ & $131-134$ & $114-116$ & 116 & $115-116$ & $116-118$ \\
\hline \multirow{4}{*}{ Solubility (mg/mL) } & Initial & 0.01513 & 0.0151 & 0.926 & 1.516 & 0.9261 & 1.516 \\
\hline & 1 month & 0.01518 & 0.0131 & 1.016 & 1.202 & 1.077 & 1.159 \\
\hline & 2 month & 0.01464 & 0.0136 & 1.126 & 1.268 & 1.126 & 1.308 \\
\hline & 3 month & 0.01445 & 0.0131 & 0.913 & 1.070 & 1.020 & 1.149 \\
\hline \multirow{4}{*}{ In vitro dissolution (\%) } & Initial & 52.01 & 52.01 & 98.32 & 98.89 & 98.32 & 98.89 \\
\hline & 1 month & 64.76 & 65.49 & 98.78 & 94.51 & 99.26 & 99.45 \\
\hline & 2 month & 64.81 & 64.81 & 98.74 & 98.39 & 98.74 & 98.39 \\
\hline & 3 month & 64.06 & 63.63 & 99.53 & 99.74 & 98.69 & 98.81 \\
\hline \multirow{4}{*}{ Drug content } & Initial & - & - & 95.87 & 95.88 & 95.87 & 95.88 \\
\hline & 1 month & - & - & 95.70 & 95.3 & 95.74 & 95.57 \\
\hline & 2 month & - & - & 95.2 & 94.96 & 95.47 & 95.90 \\
\hline & 3 month & - & - & 95.00 & 95.05 & 95.08 & 95.59 \\
\hline
\end{tabular}


(cocrystals). The formation of cocrystals based on the PXRD pattern was reported and showed new peaks that differ from the peaks corresponding to its input components. ${ }^{30,31}$

In vitro dissolution study

The dissolution rate plays a crucial role in the bioavailability of drugs with poor solubility. The dissolution experiment was

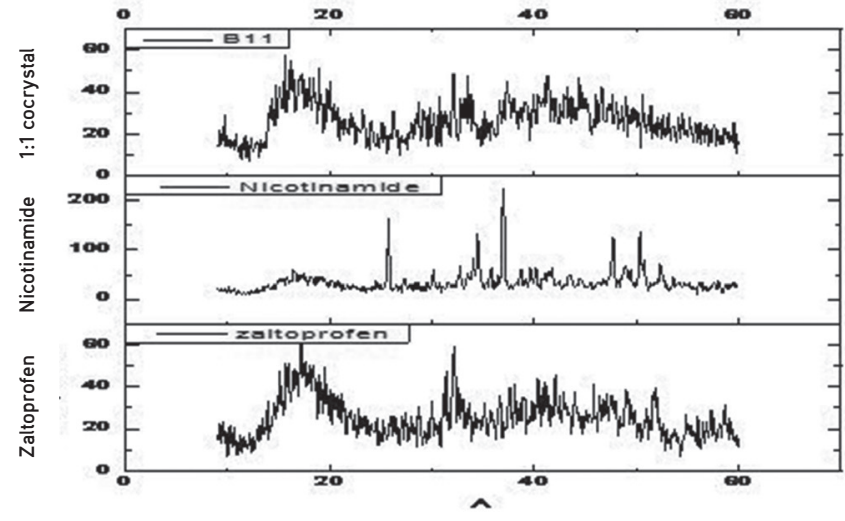

Figure 4. Overlay PXRD pattern for 1:1 cocrystal (1:1 cocrystal) PXRD: Powder X-ray diffraction

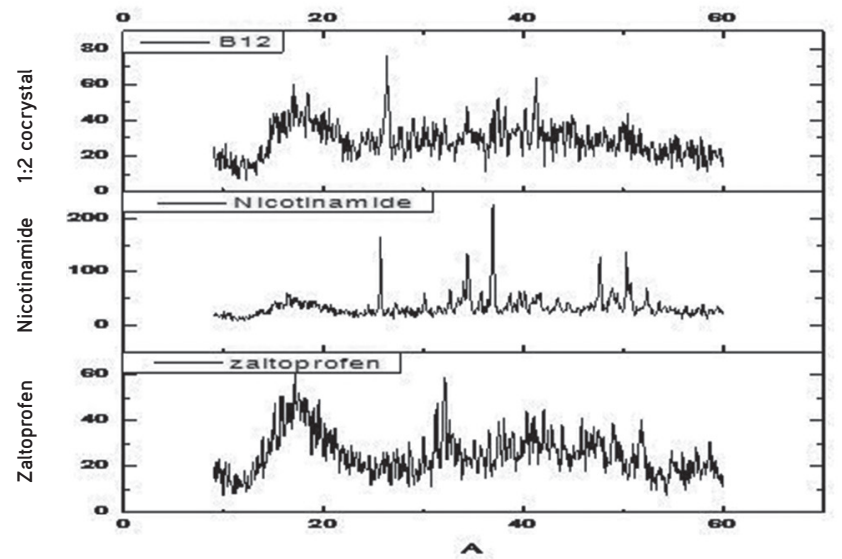

Figure 5. Overlay PXRD pattern for 1:2 cocrystal (1:2 cocrystal) PXRD: Powder X-ray diffraction

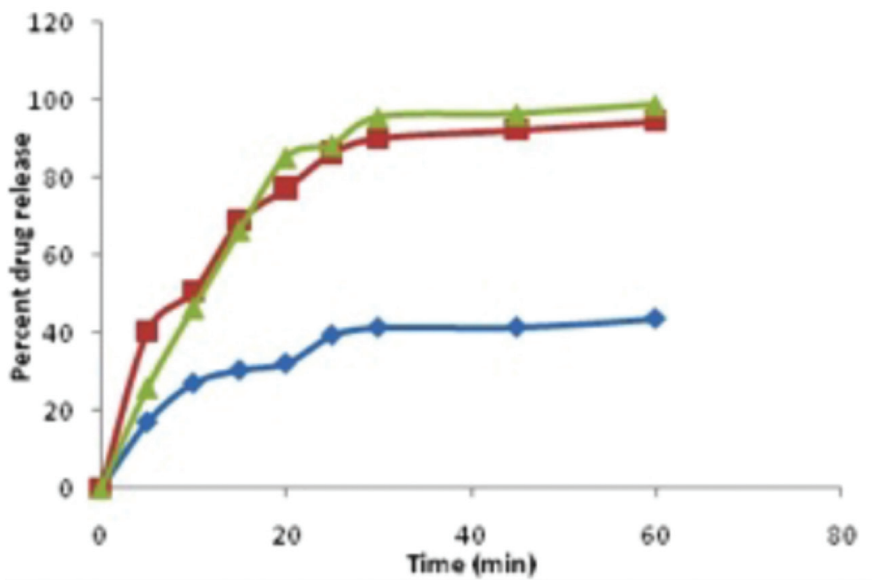

Figure 6. In vitro drug release conducted on the pure drug and cocrystals. The dissolution profile of the pure drug and the prepared cocrystals is shown in Figure 6. The dissolution profile of the pure drug indicates a slow dissolution rate with only $27.17 \pm 0.89 \%$ of the drug being dissolved in the first $10 \mathrm{~min}$. The total amount of drug dissolved in $60 \mathrm{~min}$ was $43.82 \pm 1.06 \%$ and the calculated dissolution efficiency was only $27.4 \%$. However, cocrystals of the ZFN resulted in a substantial increase in the dissolution rate. The amount of drug dissolved in first 10 min was $50.66 \pm 0.32 \%$ and $46.67 \pm 0.65 \%$ for the $1: 1$ and 1:2 cocrystals, respectively. The maximum amount of drug dissolved was $98.89 \pm 0.48 \%$ for the $1: 2$ cocrystal with dissolution efficiency of $86.71 \%$, whereas it was $94.14 \pm 0.91 \%$ for the $1: 1$ cocrystal, having a dissolution efficiency of $81.78 \%$. This can indicate a weaker crystalline structure of the formed cocrystal as evident from the higher dissolution rate. Moreover, greater dissolution of ZFN from the cocrystal can be attributed to enhanced solubility of the cocrystal in the dissolution media. Cocrystallization had been well documented as a suitable technique for dissolution enhancement. ${ }^{32}$ The similarity factor test denoting the dissolution of pure drug showed dissimilarity to the prepared cocrystals (F2 value $20 \%$ and $22 \%$ for $1: 1$ and $1: 2$ cocrystals).

\section{Stability study}

The drug and cocrystals were subjected to a stability study at room temperature and accelerated conditions for 3 months to assess the stability of cocrystals. All the cocrystals were stable at both storage conditions and no substantial change in the estimated parameters like melting point, solubility, in vitro drug release, and drug content was obtained except ZFN:NIC 1:2 cocrystal solubility at accelerated conditions. However, the pure drug exhibited changes in solubility and percent dissolution during the stability period, indicating instability. Hence cocrystal stability was enhanced in comparison to the pure drug. This demonstrates the potential of cocrystals to improve drug stability. Similar results have been reported for theophylline. ${ }^{33}$ The results are given in Table 2 .

\section{CONCLUSIONS}

Dry grinding of ZFN with NIC resulted in cocrystal formation. This was ascertained by melting point transformations, DSC changes, shifts in infrared bands, and changes in $2 \theta$ values in XRPD that mutually supported each other. The newly prepared cocrystals exhibited greater solubility and dissolution as compared to the pure drug and were stable at room temperature and accelerated conditions. The study endorsed the high potential of the technique for future applications with other drugs.

Conflict of interest: No conflict of interest declared by authors.

\section{REFERENCES}

1. Schultheiss N, Newman A. Pharmaceutical cocrystals and their physicochemical properties. Cryst Growth Des. 2009;9:2950-2967.

2. Miroshnyk I, Mirza S, Sandler N. Pharmaceutical co-crystals-an opportunity for drug product enhancement. Expert Opin Drug Deliv. 2009;6:333-341. 
3. Blagden N, De Matas M, Gavan PT, York P. Crystal engineering of active pharmaceutical ingredients to improve solubility and dissolution rates. Adv Drug Deliv Rev. 2007;59:617-630.

4. Qiao N, Li M, Schlindwein W, Malek N, Davies A, Trappitt G. Pharmaceutical cocrystals: an overview. Int J Pharm. 2011;419:1-11.

5. Bolla G, Nangia A. Pharmaceutical cocrystals: walking the talk. Chem Commun. 2016;52:8342-8360.

6. Steed JW. The role of co-crystals in pharmaceutical design. Trends Pharmacol Sci. 2013;34:185-193.

7. Krishnamohan Sharma CV. Crystal Engineering-Where Do We Go from Here? Cryst Growt Des. 2002;2:7-10.

8. Rodríguez-Hornedo N. Cocrystals: Molecular design of pharmaceutical materials. Mol Pharm. 2007;4:299-300.

9. Box KJ, Comer J, Taylor R, Karki S, Ruiz R, Price R, Fotaki N. Small-Scale Assays for Studying Dissolution of Pharmaceutical Cocrystals for Oral Administration. AAPS Pharm Sci Tech. 2016;17:245-251.

10. Rahman Z, Agarabi C, Zidan AS, Khan SR, Khan MA. Physico-mechanical and stability evaluation of carbamazepine cocrystal with nicotinamide. AAPS Pharm Sci Tech. 2011;12:693-704.

11. Rodriguez-Aller M, Guillarme D, Veuthey JL, Gurny R. Strategies for formulating and delivering poorly water-soluble drugs. J Drug Deliv Sci Technol. 2015;30:342-351.

12. Kale DP, Zode SS, Bansal AK. Challenges in Translational Development of Pharmaceutical Cocrystals. J Pharm Sci. 2017;106:457-470.

13. Perlovich GL, Manin AN. Design of pharmaceutical cocrystals for drug solubility improvement. Russ J Gen Chem. 2014;84:407-414.

14. Gadade DD, Pekamwar SS. Pharmaceutical Cocrystals: Regulatory and Strategic Aspects, Design and Development. Adv Pharm Bull. 2016;6:479-494.

15. Baek J, Lim J, Kang J, Shin S, Jung S, Cho C. Enhanced transdermal drug delivery of ZFN using a novel formulation. Int J Pharm. 2013;453:358362.

16. Ratnesh M, Kedar S P, Lokesh Kumar B. Preparation, optimization, and evaluation of Zaltoprofen-loaded microemulsion and microemulsionbased gel for transdermal delivery. J Liposome Res. 2016;26:297-306.

17. Shiraki K, Takata N, Takano R, Hayashi Y, Terada. K. Dissolution improvement and the mechanism of the improvement from cocrystallization of poorly water-soluble compounds. Pharm Res. 2008;25:2581-2592.

18. Goud NR, Gangavaram S, Suresh K, Pal S, Manjunatha SG, Nambiar S, Nangia A. Novel furosemide cocrystals and selection of high solubility drug forms. J Pharm Sci. 2012;101:664-680.
19. Rodriguez-Aller M, Guillarme D, Veuthey JL, Gurny R. Strategies for formulating and delivering poorly water-soluble drugs. J Drug Deliv Sci Technol. 2015;30:342-351.

20. Shan N, Perry ML, Weyna DR, Zaworotko MJ. Impact of pharmaceutical cocrystals: the effects on drug pharmacokinetics. Expert Opin Drug Metab Toxicol. 2014;10:1255-1271.

21. Maddileti D, Jayabun SK, Nangia A. Soluble cocrystals of the xanthine oxidase inhibitor febuxostat. Cryst Growth Des. 2013;13:3188-3196.

22. Nijhawan M, Santhosh A, Babu PR, Subrahmanyam CV. Solid state manipulation of lornoxicam for cocrystals--physicochemical characterization. Drug Dev Ind Pharm. 2014;40:1163-1172.

23. Yamamoto K, Tsutsumi S, Ikeda Y. Establishment of cocrystal cocktail grinding method for rational screening of pharmaceutical cocrystals. Int J Pharm. 2012;437:162-171.

24. Ganesh M, Jeon UJ, Ubaidulla U, Hemalatha $P$, Saravanakumar $A$, Peng MM, Jang HT. Chitosan cocrystals embedded alginate beads for enhancing the solubility and bioavailability of aceclofenac. Int J Biol Macromol. 2015;74:310-317.

25. El-Gizawy SA, Osman MA, Arafa MF, El Maghraby GM. Aerosil as a novel co-crystal co-former for improving the dissolution rate of hydrochlorothiazide. Int J Pharm. 2015;478:773-778.

26. Patil SP, Modi SR, Bansal AK. Generation of 1: 1 carbamazepine: nicotinamide cocrystals by spray drying. Eur. J. Pharm. Sci. 2014;62:251257.

27. Shayanfar A, Jouyban A. Physicochemical characterization of a new cocrystal of ketoconazole. Powder Technol. 2014;262:242-248.

28. Panzade P, Shendarkar G, Shaikh S, Rathi P. Pharmaceutical Cocrystal of Piroxicam: Design, formulation and evaluation. Adv Pharm Bull. 2017;7399-408.

29. Yadav AV, Dabke AP, Shete AS. Crystal engineering to improve physicochemical properties of mefloquine hydrochloride. Drug Dev Ind Pharm. 2010;36:1036-1045.

30. Sarkar A, Rohani S. Molecular salts and co-crystals of mirtazapine with promising physicochemical properties. J Pharm Biomed Anal. 2015;110:93-109.

31. Sanphui P, Kumar SS, Nangia A. Pharmaceutical cocrystals of niclosamide. Cryst Growth Des. 2012;12:4588-4599.

32. Mulye SP, Jamadar SA, Karekar PS, Pore YV, Dhawale SC. Improvement in physicochemical properties of ezetimibe using a crystal engineering technique. Powder Technol. 2012;222:131-138.

33. Trask AV, Motherwell WS, Jones W. Physical stability enhancement of theophylline via cocrystallization. Int J Pharm. 2006;320:114-123. 